Available online on 15.01.2020 at http://jddtonline.info
Open Access to Pharmaceutical and Medical Research
unrestricted non-commercial use, provided the original work is properly cited

Open Access

Research Article

\title{
Evaluation of the Antiasthmatic Activity of Methanolic Extract of Trigonella Foenum Graecum on Experimental Models of Bronchial Asthma
}

\author{
Pankaj G Jain*, Pramod P Patil, Sushil D Patil, Savita D Patil, Sanjay J. Surana \\ R.C. Patel Institute of Pharmaceutical Education and Research, Near Karwand Naka, Shirpur- 425 405, Dist- Dhule, Maharashtra, India.
}

\begin{abstract}
The present study deals with the phytochemical screening and evaluation of antiasthmatic activity of methanolic extract of Trigonella foenumgraecum on experimental models of bronchial asthma and anaphylaxis. The antiasthmatic activity was studied on histamine-induced bronchospasm in guinea pig (Dunkey-Hartley) for respiratory parameters such as maximum airflow, minimum airflow, tidal volume, respiratory rate, minute volume, specific airway resistance determination on double chambered whole body plethysmography on unanesthetized guinea pigs, for mast cell degranulation by compound 48/80 (in vitro) was done using rat (Albino Wistar) peritoneal fluid. Trigonella foenum graecum treated result indicated significant protection against histamine-induced bronchospasm in guinea pigs at highest dose i.e. $400 \mathrm{mg} / \mathrm{kg}$. The bronchodilatory effect of Trigonella foenum graecum was found comparable to the protection offered by the standard drug Salbutamol on respiratory parameters in double chambered whole body plethysmography, Treatment with Trigonella foenum graecum at a dose of $400 \mathrm{mg} / \mathrm{kg}$ showed a significant decrease in degranulation rate of actively and passively sensitized mast cells of sensitized rats when challenged with antigen. Trigonella foenum graecum. Possess significant anti-asthmatic activity due to its potential anti inflammatory, antioxidant and the antihistaminic activity, which reflects as anti-degranulating effect on mast cells and on respiratory parameters.
\end{abstract}

Keywords: Trigonella foenum graecum; asthma; mast cell; compound 48/80; histamine

Article Info: Received 10 Nov 2019; Review Completed 25 Dec 2019; $\quad$ Accepted 04 Jan 2020; Available online 15 Jan 2020

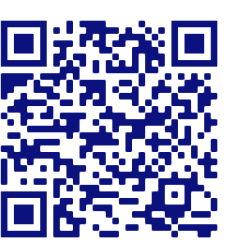

\section{Cite this article as:}

Jain PG, Patil PP, Patil SD, Patil SD, Surana SJ, Evaluation of the Antiasthmatic Activity of Methanolic Extract of Trigonella Foenum Graecum on Experimental Models of Bronchial Asthma, Journal of Drug Delivery and Therapeutics. 2020; 10(1):101-106 http://dx.doi.org/10.22270/jddt.v10i1.3924

Dr. Pankaj G. Jain, Assistant Professor, Department of Pharmacology, R.C. Patel Institute of Pharmaceutical Education and Research, Near Karwand Naka, Shirpur- 425 405, Dist- Dhule, Maharashtra, India.

\section{INTRODUCTION:}

Asthma is a serious condition in which the bronchial tubes become swollen, hyperproduction of mucus results in a reduction in size, which is characterized by airway inflammation and difficulty in breathing. ${ }^{1}$ All of these pathological changes in asthma are mediated by common inflammatory mediators like histamine, tryptase, and other neutral proteases, leukotrienes C4 \& D4 and prostaglandins which are released by infiltrating of inflammatory cells, including eosinophils, mast cells, and lymphocytes responsible for the early reaction (immediate bronchoconstriction). ${ }^{2}$ Asthma is a complex disease in which the repeated exposure of many types of allergens leads to aggravation of asthma attack some of them are dust particles, pollens, exercise, pets in houses, insects like- dust mites in mattresses, pillows, carpets, curtains smoke from tobacco, wood, agarbattis, changes in weather foods drugs like aspirin, $\beta$-blockers and viral respiratory infections. ${ }^{3}$ Asthma affects over 20 million individuals in the US and over 60 million individuals worldwide. It affects over $5-10 \%$ of the population in industrialized countries.4,5 In India 57.5 estimated total deaths (2,000); 5.1 estimated deaths per 100000 population; 277 DALYs (disability-adjusted life-year) per 100,$000 ; 6.5$ age-standardized deaths per 100,000; constitutes $0.2 \%$ of all deaths and $0.5 \%$ of National burden of diseases. $[4,5]$ Common symptoms which observed in asthma are a shortness of breath, wheezing, coughing and a tight feeling in the chest. ${ }^{6}$ Even though research in respiratory medicine is in advanced stages, respiratory diseases are still one of the perpetrators of global health. Despite the availability of a wide range of drugs such as steroids, $\beta 2$ agonists, anticholinergic and phosphodiesterase (PDE) inhibitors, the relief offered by them is mainly symptomatic, short-lived and have numerous adverse effects. For example, longer use of corticosteroids produces a deficiency in bone mineral density, cardiovascular effects, osteoporosis and osteonecrosis, the risk of cataract, panniculitis, migraine or a migraine-like headache, pharyngitis and sore throat and renal deterioration. Most recently, it has been reported to cause serious pneumonia also. The long-acting $\beta_{2-}$ adrenoreceptor agonists produce myocardial ischemia and 
osteoporosis. Anticholinergics cause papillary dilation, blurred vision, and acute glaucoma. PDE inhibitors like theophylline cause gastrointestinal symptoms to palpitations, arrhythmias, hypocalcemia, nausea diarrhea,and headache, Hence the search for a new drug is still the need of the day.7,8 Trigonella foenum gracecum. (Fabaceae) is commonly known as "Methi" in Hindi, and is used as a vegetable and cultivated throughout India, Sri Lanka, and many other tropical countries. ${ }^{9}$ The plant contains steroids, saponins, ß-sitosterol, flavonoids, terpenoids, glycosides, alkaloids, phenolic compounds, betalains, tannins, amino acids, lysine and tryptophan, and 4hydroxyisoleucine,Steroidal saponins (fenugreek in diosgenin) flavonoids as flavone glycosides (apigenin, luteolin, quercetin), Coumarins. ${ }^{10,} 11$ Tribal people use decoction (15-20 ml) of the whole plant thrice daily in allergic bronchitis and asthma as folk medicine ${ }^{11}$ However, no scientific studies are carried out to investigate the antiasthmatic and anti-anaphylactic effect of seeds of Trigonella foenum gracecum, Hence the present study is carried out to evaluate the anti-asthmatic activity of seeds of Trigonella foenum gracecum. ${ }^{7,8}$ Therefore, need to develop the novel treatment for asthma with fewer side effects, and for this purpose, Trigonella foenum-graecum which is natural product can be used as new therapy. However, its exact effects on allergic asthma have been still rarely studied, and need to be verified. In the present study, we aimed to investigate the effects of Trigonella foenum-graecum on airway inflammation of allergic asthma in Histamine-induced bronchospasm in guinea pigs, Restrained double chamber body plethysmography measurements, Compound 48/80induced Mast cell degranulation.

\section{MATERIALS AND METHODS:}

\section{Plant material:}

The plant was collected from a local area of Chopda in Maharashtra state in the month of March and May. The plant was authenticated by Dr. S. R. Kshirsagar, Reader, P.G. Department of Botany, S.S.V.P.S Science College, Dhule- 425 405 (MS).The Seeds were dried under shade and then powdered. The powder was then extracted with $70 \%$ methanol by using soxhlet apparatus.

\section{Phytochemical investigations:}

The obtained methanolic extract was tested for various chemical constituents with the help of qualitative chemical tests.[12]

\section{Animals:}

Adult Guinea pig (Dunkey-Hartley) of body weight 500-700 g and Mice (Swiss Albino) of body weight25-30 gm mice of either sex obtained from Wokhart institute, Aurangabad was used for the experiment.
Rat (Albino Wistar) of body weight 200-250 g were obtained from in-house animal house facility of the institute, Standard conditions of temperature $(22 \pm 2 \mathrm{oC})$, relative humidity (60 $\pm 5 \%$ ) and light (12 hrs light/dark cycles) were maintained, standard feed and water were given ad libitum. The study was approved by the Institutional Animal Ethics Committee (IAEC) of R.C.P.I.P.E.R, Shirpur, India and according to CPCSEA guideline. Registration no: 651/02/c/CPCSEA.

\section{Histamine-induced bronchospasm in guinea pigs}

Histamine-induced bronchospasm in guinea pigs was carried out by the reported method ${ }^{13-15}$ Adult Guinea pigs of weight around 500-700 gm of either sex were divided into 5 groups (From I to V) Control group receives $1 \mathrm{ml}$ of saline solution while standard group receives Chlorpheniramine maleate 2 $\mathrm{mg} / \mathrm{kg}$ and the remaining 3 groups receives $200 \mathrm{mg} / \mathrm{kg}$, $300 \mathrm{mg} / \mathrm{kg}$, and $400 \mathrm{mg} / \mathrm{kg}$ respectively. Twenty-five guinea pigs then were exposed to $0.5 \%$ histamine diphosphate $\mathrm{H}$ 7375 (Sigma chemicals 23297-93-0) with constant pressure $40 \mathrm{~mm} / \mathrm{Hg}$ in an aerosol chamber to induce experimental bronchial asthma. This PCT was considered as $\mathrm{T}_{1}$ value. These animals were subjected to histamine challenge two and a half hr. after receiving the drug. The PCT was noted. This PCT was considered as $\mathrm{T}_{2}$ value. Animals which withstood exposure to histamine aerosol for 15 min were considered to be completely protected. The protection offered by the treatment was calculated by the following formula.

$$
\text { Percentage protection }=\left\{1-\frac{T_{1}}{T_{2}}\right\} \times 100
$$

Where; T1 is a time in second for PCT before treatment T2 is the time in second for PCT after treatment.

\section{Restrained double chamber body plethysmography measurements for histamine-induced bronchoconstriction in unanesthetized guinea pigs}

Awaken guinea pigs were divided into different groups as shown in table no. 1 and individually placed in a body plethysmograph box (HSE type 855, Hugo Sachs Elektronik, Germany) and were exposed to histamine in a concentration of $0.5 \%$ solution for 10 seconds. ${ }^{16}$ The histamine aerosol was generated by a jet nebulizer (PARI Jet-Nebulizer requires an operating pressure of approx. 1.5 bar., $100 \%$ of the particles are below $10 \mu \mathrm{m}$ ) are delivered to the head chamber of the plethysmograph and respiratory frequency and amplitude were recorded. Respiratory function in animals was evaluated by measurement of ventilatory parameters [respiratory rate (RR), tidal volume (VT) and minute ventilation, specific airway resistance measurement (RV)].

Table 1: Experimental design for histamine induced bronchospasm.

\begin{tabular}{lccc}
\hline Groups (n) & Name of group & Drug received & Dose (p.o.) \\
\hline Group I (5) & Control & Normal saline & $1 \mathrm{~mL}$ \\
Group II (5) & Test drug & TFME & $200 \mathrm{mg} / \mathrm{kg}$
\end{tabular}

$\begin{array}{lccc}\text { Group III (5) } & \text { Test drug } & \text { TFME } & 300 \mathrm{mg} / \mathrm{kg} \\ \text { Group IV (5) } & \text { Test drug } & \text { TFME } & 400 \mathrm{mg} / \mathrm{kg} \\ \text { Group V (5) } & \text { Standard drug (Std.) } & \text { Chlorpheniramine maleate } & 2 \mathrm{mg} / \mathrm{kg}\end{array}$




\section{Compound 48/80-induced Mast cell degranulation:}

Wistar rats of weight around 150-180 g of either sex were divided into six groups containing six animals in each. Normal control group receives only methylcellulose suspension $0.1 \mathrm{ml}$ while all remaining groups receive compound 48/80 $(10 \mu \mathrm{g} / \mathrm{ml})$ standard treated group receives Ketotifen $(10 \mathrm{mg} / \mathrm{ml})$ Test I, Test II and Test III receives TFME $200 \mathrm{mg} / \mathrm{kg}, 300 \mathrm{mg} / \mathrm{kg}$ and $400 \mathrm{mg} / \mathrm{kg}$ respectively 17,18 .The suspensions were further incubated for $10 \mathrm{~min}$ at $37^{\circ} \mathrm{C}$. The peritoneal mast cells were stained with toluidine blue and examined microscopically for intact and disrupted mast cells. A minimum of 100 cells was counted for the number of intact and degranulated mast cells.

\section{Statistical analysis:}

The results of various studies were expressed as mean \pm SEM and analyzed statistically using One-way ANOVA followed by Dunnett's multiple comparative post-test to find out the level of significance. $\mathrm{P}<0.05$ was considered statistically significant. The analysis was performed using the GraphPad Prism software package (version 5.0).

\section{RESULTS}

\section{Phytochemical Screening:}

TFME showed the presence of amino acids, proteins, Carbohydrates, Alkaloids and saponins like steroids and triterpenoids while showed the absence of Tannins, Flavonoids.

\section{\% yield:}

The yield of TFME was found to be $8.77 \% \mathrm{w} / \mathrm{w}$.

\section{Acute toxicity study:}

LD50 was reported ${ }^{20}$ Acute Oral Toxicity $>5 \mathrm{gm} / \mathrm{kg}$ Acute Dermal Toxicity $>2 \mathrm{gm} / \mathrm{kg}$

\section{Bronchial hyperactivity:}

\section{Histamine-induced bronchospasm in guinea pigs}

Preconvulsion time is directly proportional to bronchodilator and antihistaminic activity. The dyspnea was evoked within $30.40 \pm 1.54$ seconds in the control group on exposure of histamine aerosol, In case of standard (Chlorpheniramine), it was 209.40 \pm 12 .20seconds. While after the treatment with $T$. foenum graecum at a dose of 200 , $300,400 \mathrm{mg} / \mathrm{kg}$, p.o., of extract PCT was prolonged up to $65.00 \pm 10.9,132 \pm 8.17,184 \pm 12.3$ seconds under same conditions. The result indicates that $T$. foenum graecum at200, 300 and $400 \mathrm{mg} / \mathrm{kg}$ showed significant protection when compared with chlorpheniramine maleate.

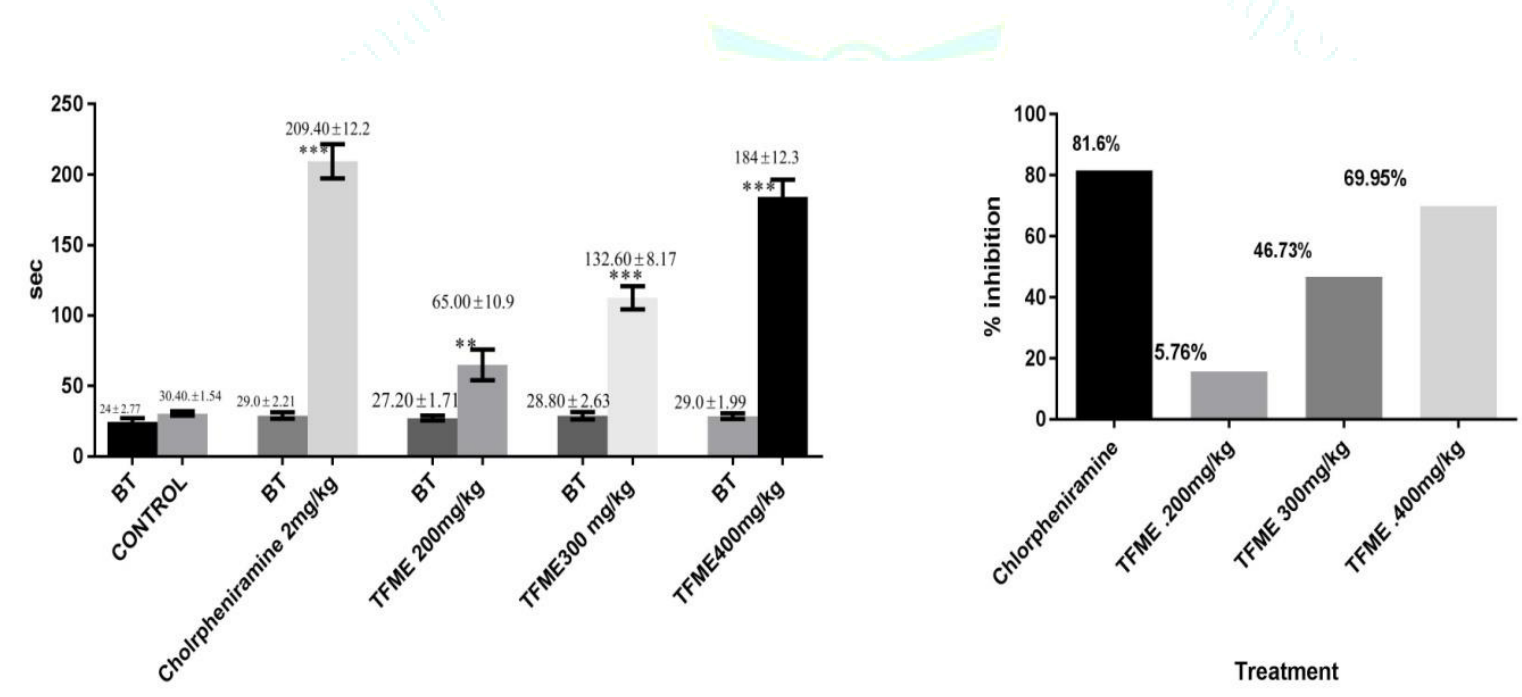

A

B

Figure 1: A. Effect of methanolic extract of T. foenum graecum on histamine aerosol-induced bronchospasm B. Effect of methanolic extract of $T$. foenum graecum Protection against histamine-induced bronchospasm Value represents, Mean \pm S.E.M. $(\mathrm{n}=5)$ ANOVA: Dunnett's Multiple Comparative test ${ }^{*} \mathrm{p}<0.05,{ }^{* *} \mathrm{p}<0.01,{ }^{* * *} \mathrm{p}<0.001$ as Compared with Control.

\section{Restrained double chamber whole body plethysmography measurements for histamine-induced bronchoconstriction in unanesthetized guinea pigs:-}

Histamine inhalation in double chamber whole body plethysmography shows decreased in a respiratory amplitude (diminished respiratory volume due to bronchoconstriction) and the reflectory increase of respiratory frequency, this seems to be attenuated by $T$. foenum graecum at the concentration of 200,300and 400 $\mathrm{mg} / \mathrm{kg}$ showed elevations in Respiratory function by measurement of ventilatory parameters [respiratory rate (RR), tidal volume (VT) and minute ventilation, specific airway resistance measurement (RV)]. 


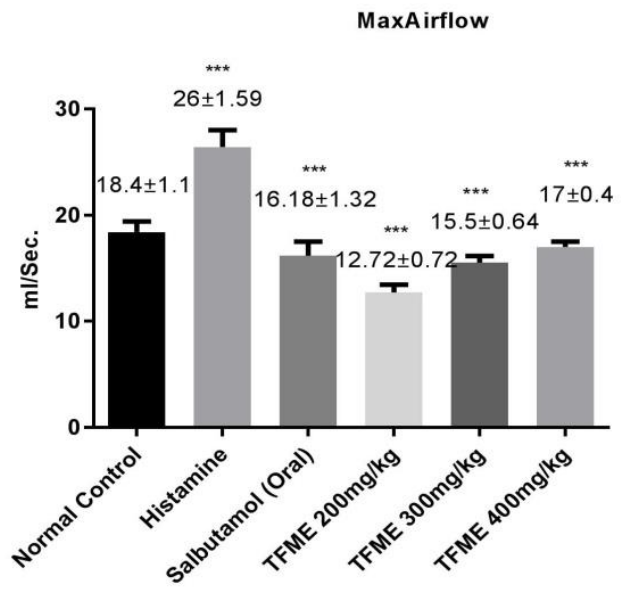

$\mathbf{A}$

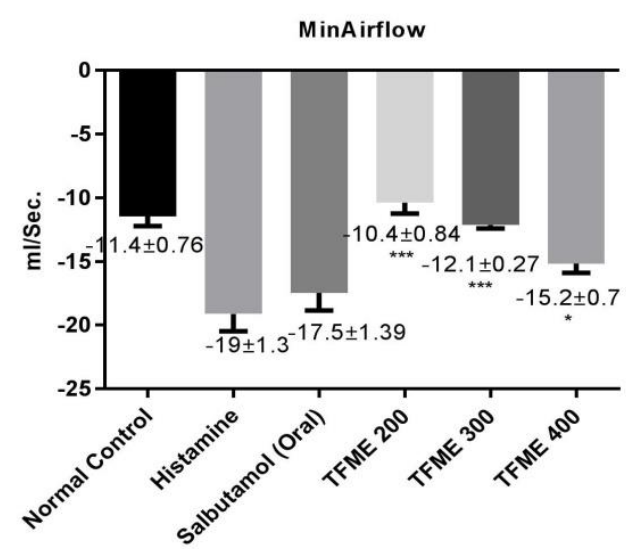

B

Figure 2: Effect of methanolic extract of T.foenum graecum on (A) Maximum airflow (B) Minimum Airflow.

TidalVol.

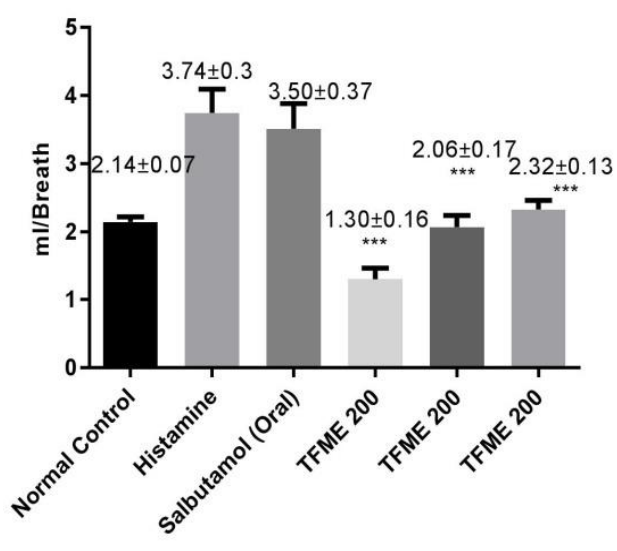

$\mathbf{A}$

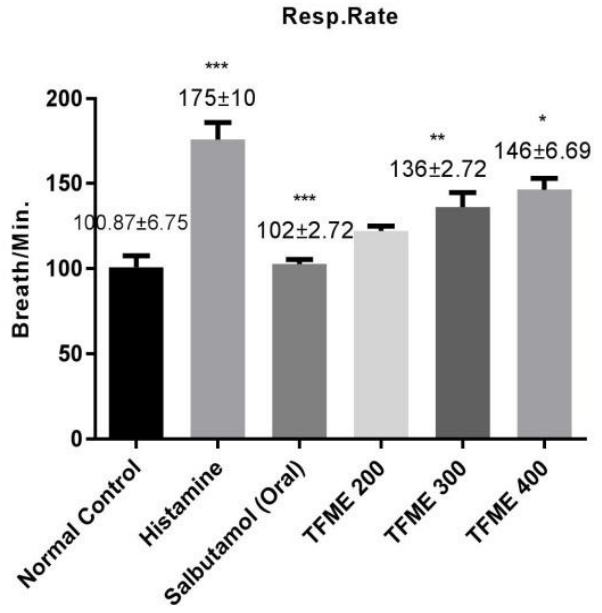

B

Figure 3: Effect of methanolic extract of T.foenum graecum on (A) Tidal Volume (B) Respiratory Rate.

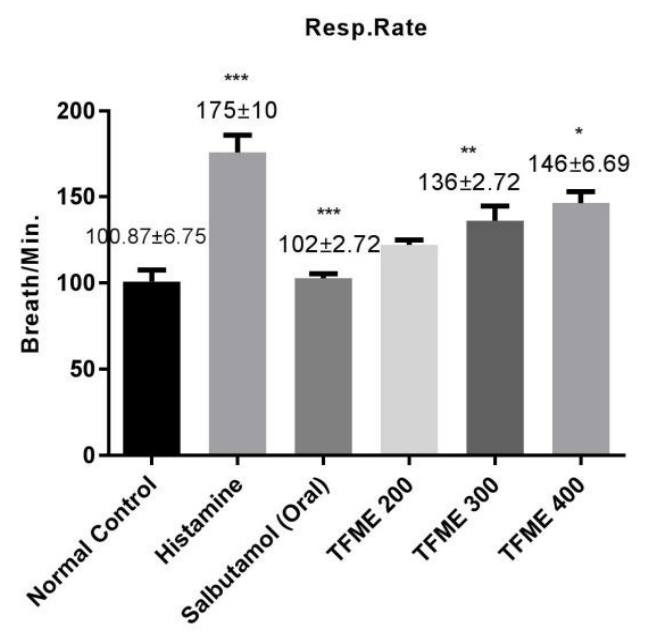

A

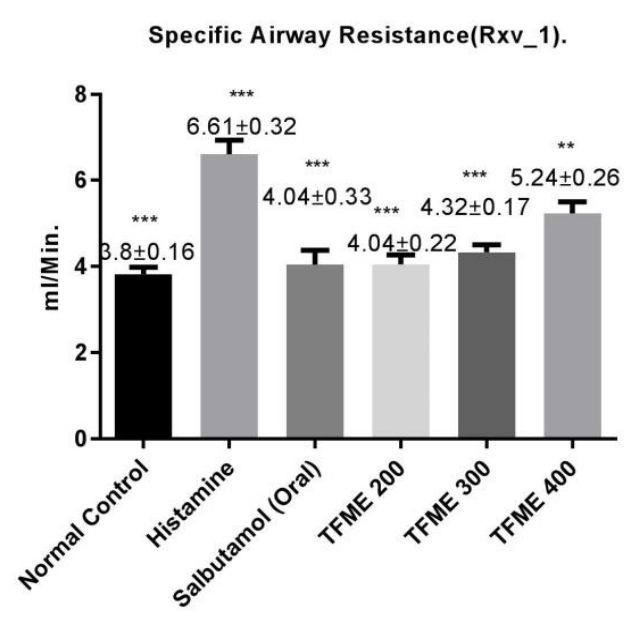

B

Figure 4: Effect of methanolic extract of T.foenum graecum on (A) Minute volume (B) Specific Airway Resistance (Rxv_1). Values are expressed as mean \pm SEM $(n=6)$, One way ANOVA: Dunnett's Multiple Comparative Test. \#p $<0.01$ when compared with normal control group, ${ }^{*} \mathrm{p}<0.05,{ }^{* *} \mathrm{p}<0.01,{ }^{* * *} \mathrm{p}<0.001$ when compared with Histamine. 


\section{Evaluation of Mast Cell Stabilization Activity:-}

\section{Compound 48:80-induced Mast cell degranulation:}

Compound 48/80 (10 $\mu \mathrm{g} / \mathrm{ml})$ produced about $77.2 \%$ degranulation of mast cells as compared to normal control group. Groups treated with standard drug Ketotifen (0.1 $\mathrm{mg} / \mathrm{ml}$ ) showed $75 \pm 1.91(\mathrm{p}<0.01)$ intact mast cells whereas T. foenum graecum showed significant $(\mathrm{p}<0.01)$ and dose- dependent protection against the mast cell degranulation compared to Compound 48/80 group. T. foenum graecum at the concentration of 200, 300and $400 \mathrm{mg} / \mathrm{kg}$ showed38.2 $\pm 1.7,51.7 \pm 2.2$ and $63.3 \pm 1.50 \%$ intact mast cells respectively. Standard reference Ketotifen $(0.1 \mathrm{mg} / \mathrm{ml})$ showed comparative mast cell stabilization with $T$. foenum graecum.

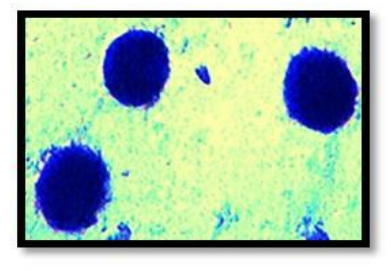

\section{Normal Control}

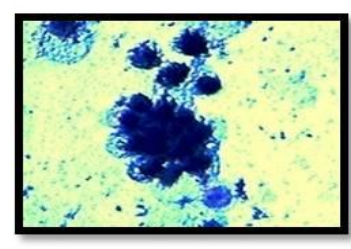

TFME 200mg/kg TFME 300mg/kg

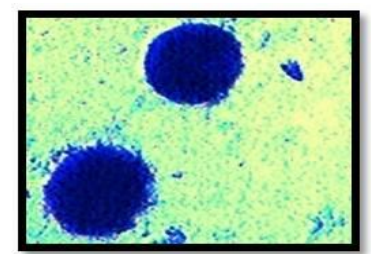

Ketotefen

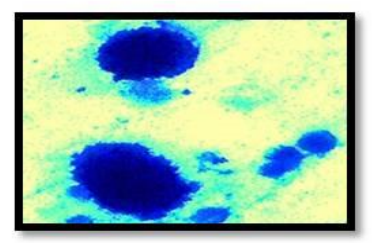

TFME 400mg/kg

Figure 5: Images of granulated \& de-granulated mast cells.

Intact cells

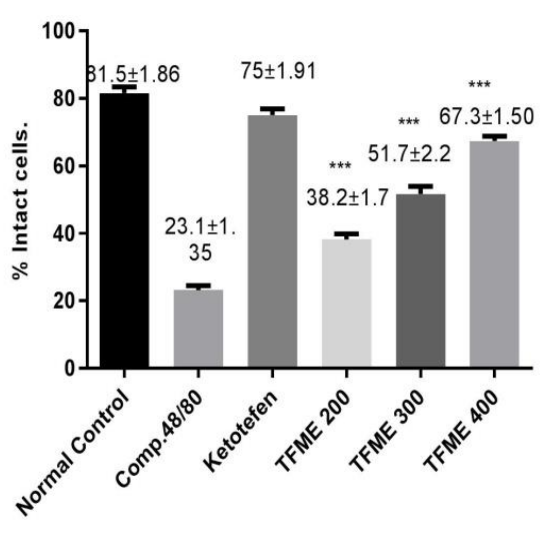

A
Degranulated cells

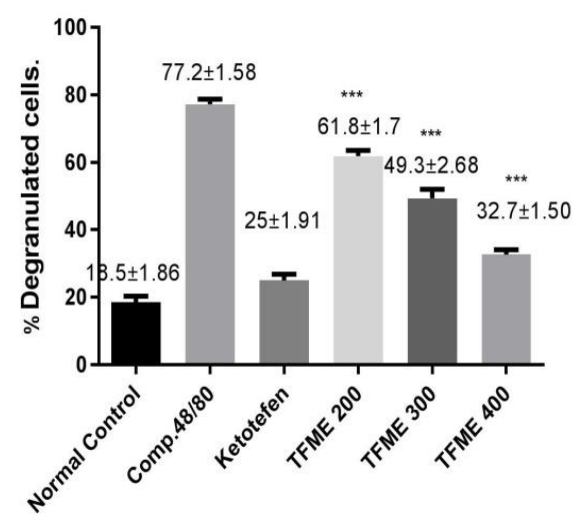

B

Figure 6: Effect of methanolic extract of T.foenum graecum on compound 48/80 induced Mast cell degranulation: (A) Intact Cells (B) Degranulated cells Values are expressed as mean \pm SEM $(n=6)$, One Way ANOVA: Dunnett's Multiple Comparative Test. $\# \mathrm{p}<0.01$ when compared with normal control group, ${ }^{*} \mathrm{p}<0.05,{ }^{* *} \mathrm{p}<0.01,{ }^{* * *} \mathrm{p}<0.001$ when compared with Sensitized Control.

\section{DISCUSSION}

The bronchoconstriction appeared in the early stage of asthma is caused due to the release of inflammatory mediators like histamine, leukotrienes, prostaglandins, tryptase, and acetylcholine. $15 \mathrm{~T}$. foenum graecum seems to be a promising plant for treatment of bronchial asthma because the plant is a rich source of different phytoconstituents with a variety of potential biological activities and for bronchodilation activity. T. foenum graecum proved Antiinflammatory activity. The plant contains steroidal Saponins which inhibits the release of several mediators of the phlogistic agents such as prostaglandins, histamine, serotonin, and bradykinin by inhibiting the biosynthetic pathways of inflammatory mediators. Evidence strongly suggests that steroidal Saponins present in the extracts obtained from $T$. foenum graecum may interfere with lipoxygenase and/or cyclo-oxygenase pathway, Histamine is an important mediator of immediate allergic and inflammatory reaction and it induce bronchoconstriction, it acts through $\mathrm{H} 1$, receptors through the IP3-DAG pathway, 
releases $\mathrm{Ca} 2+$ from intracellular stores and protein kinase-C activation. ${ }^{21}$ In the present study histamine, $0.5 \%$ solution acts as spasmogens in the form of aerosols for 10 Sec. to cause significant bronchoconstriction in and it results into an overall reduction in airway due to bronchoconstriction in guinea pigs. In the reference standard group, we used the standard drug Chlorpheniramine maleate and Salbutamol against histamine-induced bronchospasm. The crude methanolic extract at a dose of $200 \mathrm{mg} / \mathrm{kg}, 300 \mathrm{mg} / \mathrm{kg}$, and $400 \mathrm{mg} / \mathrm{kg}$ orally $30 \mathrm{~min}$. before the histamine challenge has shown significant bronchoprotection against spasmogens as compared to control the significant effect produced may be due to the inhibition of IP3-DAG pathway or inhibition of releases of $\mathrm{Ca} 2+$ from intracellular stores or inhibition of protein kinase-C activation. The bronchodilatory effect of T.foenum graecum was found comparable to the protection offered by the standard drug Chlorpheniramine maleate and salbutamol.

Asthma is an inflammatory disease of the lungs characterized by increased infiltration of leukocytes into the airways and reduced respiratory function. The inflammation leads to bronchoconstriction, increased airway hyperreactivity, and mucus production ${ }^{22}$ after antigen challenge, inflammatory leukocytes produce various chemical mediators which are thought to be involved in both the immediate and the late asthmatic responses. During the LAR infiltration of eosinophils, neutrophils, lymphocytes, monocytes into the airways have been identified in BALF from the asthmatics ${ }^{23}$ Mast cells, which are constituents of virtually all organs and tissue, are important mediators of inflammatory responses such as allergy and anaphylaxis. Mast cell degranulation can be elicited non-immunologically by the most potent synthetic secretagogue compound $48 / 80$, which is a condensation product of N-methoxyphenylamine with formaldehyde and a high dose of which induces almost a $90 \%$ release of histamine from mast cells. To study the mechanism of anaphylaxis Compound 48/80 has been used $[17,18]$ it increases the permeability of the lipid bilayer membrane of the cell by causing a perturbation in the membrane and initiates the activation of a signal transduction pathway, which leads to degranulation and histamine release ${ }^{17}$ The intracellular calcium $\left(\mathrm{Ca}^{2+}\right)$ pathways are critical to the degranulation of mast cells. $T$. foenum graecum attenuated rate of mast cell degranulation dose-dependently as observed microscopically by toluidine blue staining.

\section{CONCLUSION}

Thus, it can be concluded from the results obtained in the present pharmacological investigation that $T$. foenum graecum possess: Anti-asthmatic activity, Anti-histaminic activity Anti-degranulating activity Anti-allergic activity this may be attributed to Mast cell stabilization, inhibiting the release of histamine from the mast cells. Further study is needed to identify, isolate, purify and evaluate active constituent present in the T. foenum graecum for its antiasthmatic activity.

\section{CONFLICT OF INTEREST}

The authors declare no conflict of interest.

\section{REFERENCES}

1. Hamid Q, Tulic M. Immunobiology of asthma. Annual review of physiology. 2009 Mar 17; 71:489-507.

2. Tagaya E, Tamaoki J. Mechanisms of airway remodeling in asthma. Allergology International. 2007; 56(4):331-40.
3. Jawla S, Mogla OP, Kumar Y. Herbal remedies for asthma: An overview. J Chem Pharm Res. 2010; 2:267-72.

4. Bogaert P, Tournoy KG, Naessens T, Grooten J. Where asthma and hypersensitivity pneumonitis meet and differ: noneosinophilic severe asthma. The American journal of pathology. 2009 Jan 1; 174(1):3-13.

5. Holgate ST. Pathogenesis of asthma. Clinical \& Experimental Allergy. 2008 Jun; 38(6):872-97.

6. Ram A, Joseph DA, Balachandar S, Singh VP. Medicinal plants from Siddha system of medicine useful for treating respiratory diseases. International Journal of Pharmaceuticals Analysis. 2009 Jan 1; 1(2):20.

7. Priya V. A review of hepatoprotective natural products. Recent Research in Science and Technology. 2010 Dec 15; 2(11).

8. Khalil MI, Ibrahim MM, El-Gaaly GA, Sultan AS. Trigonella foenum (Fenugreek) induced apoptosis in hepatocellular carcinoma cell line, HepG2, mediated by upregulation of p53 and proliferating cell nuclear antigen. BioMed research international. 2015; 2015.

9. ASHISH TF, Akhand R. Pharmacological actions and potential uses of Trigonella foenum-graecum: A review.

10. Khandelwal K. Practical pharmacognosy. Pragati Books Pvt. Ltd.; 2008 Sep 7.

11. Anil K, Ramu P. Effect of methanolic extract of Benincasa hispida against histamine and acetylcholine induced bronchospasm in guinea pigs. Indian journal of pharmacology. 2002 Sep 1; 34(5):365.

12. Mitra SK, Gopumadhavan S, Venkataranganna MV, Anturlikar SD. Antiasthmatic and antianaphylactic effect of E-721B, a herbal formulation. Indian Journal of Pharmacology. 1999 Mar 1; 31(2):133.

13. Mali R, Mahajan S, Mehta A. Studies on bronchodilatory effect of Lepidium sativum against allergen induced bronchospasm in guinea pigs. Pharmacognosy magazine. 2008 Jul 1; 4(15):189.

14. Sutovska M, Nosalova G, Franova S. The role of potassium ion channels in cough and other reflexes of the airways. Journal of Physiology and Pharmacology. 2007 Nov 1; 58(5):673-83.

15. Choi IY, Moon PD, Koo HN, Myung NY, Kim SJ, Lee JH, Han SH, Moon G, Seo SY, Sung HJ, Park RK. Observations of Forsythia koreana methanol extract on mast cell-mediated allergic reactions in experimental models. In Vitro Cellular \& Developmental Biology-Animal. 2007 Aug 1; 43(7):215.

16. Shin TY, Park JH, Kim HM. Effect of Cryptotympana atrata extract on compound 48/80-induced anaphylactic reactions. Journal of ethnopharmacology. 1999 Sep 1; 66(3):319-25.

17. Madar Z, Stark AH. New legume sources as therapeutic agents. British Journal of Nutrition. 2002 Dec; 88(S3):287-92.

18. Partridge MR, van der Molen T, Myrseth SE, Busse WW. Attitudes and actions of asthma patients on regular maintenance therapy: the INSPIRE study. BMC pulmonary medicine. 2006 Dec; 6(1):13.

19. Busse WW, Holgate S, Kerwin E, Chon Y, Feng J, Lin J, Lin SL. Randomized, double-blind, placebo-controlled study of brodalumab, a human anti-IL-17 receptor monoclonal antibody, in moderate to severe asthma. American journal of respiratory and critical care medicine. 2013 Dec 1; 188(11):1294-302.

20. Kim DY, Yang WM. Panax ginseng ameliorates airway inflammation in an ovalbumin-sensitized mouse allergic asthma model. Journal of ethnopharmacology. 2011 Jun 14; 136(1):230-5.

21. Fanta CH. Drug therapy: asthma. N Engl J Med. 2009 Jun 11; 360(10):1002-14.

22. Shi Y, Xu X, Tan Y, Mao S, Fang S, Gu W. A liver-X-receptor ligand, T0901317, attenuates IgE production and airway remodeling in chronic asthma model of mice. PLoS One. 2014; $9(3)$.

23. Jeon SG, Lee CG, Oh MH, Chun EY, Gho YS, Cho SH, Kim JH, Min KU, Kim YY, Kim YK, Elias JA. Recombinant basic fibroblast growth factor inhibits the airway hyperresponsiveness, mucus production, and lung inflammation induced by an allergen challenge. Journal of allergy and clinical immunology. 2007 Apr 1; $119(4): 831-7$. 